\title{
Somatic Chromosome Counts In Some Species Of Crassocephalum (Moench.) S. Moore (Asteraceae) In Southwestern Nigeria.
}

\author{
A. S. Oyelakin ${ }^{1 *} \&$ M. S. Ayodele ${ }^{2}$ \\ ${ }^{I}$ Department of Biology, Federal University of Technology, Akure P. M. B. 704, Akure, Ondo State, Nigeria. \\ 2 Department of Biological Sciences, Federal University of Agriculture, Abeokuta P. M. B. 2240, Abeokuta, \\ Ogun State, Nigeria.
}

\begin{abstract}
Somatic chromosome numbers of four species in the genus Crassocephalum were counted. Basic chromosome number of $n=10$ which was tentatively suggested for the genus by previous workers was confirmed. Three species, Crassocephalum rubens (Juss.ex.Jacq) S. Moore, C. biafrae (Oliv.\& Hiern) S. Moore and C. togoense C.D. Adams had chromosome numbers of $2 n=20$ while $2 n=40$ was reported for the C. crepidioides (Benth.) S. Moore. The occurence of higher chromosome number in C. crepidioides suggests the species to be polyploid. Basic chromosome number of $n=10$ was confirmed for the genus.
\end{abstract}

Key words: Crassocephalum, Basic chromososme number.

\section{Introduction}

Crassocephalum (Moench.) S. Moore occur throughout tropical Africa with 24 species. In West Africa, the genus is represented by fifteen species, with nine species reported in Nigeria. Of these, four species collected for this study are endemic to Southwestern Nigeria. (Hutchinson and Dalziel, 1963). The four species are Crassocephalum crepidioides, C. biafrae, C. rubens and, C. togoense (Hutchinson and Dalziel, 1963; Olorode, 1974; Olorode and Okoli, 1978). Crassocephalum constitutes special delicacies in the Southwestern, Nigeria and feature prominently among numerous edible plants common to the Yoruba culture (Bankole et al., 2003). Crassocephalum species are regarded as neglected and under-exploited vegetables that are of economic importance (Olufolaji and Denton, 2000). The neglect is probably due to low scientific attention and paucity of information on the species. They are treated as wild vegetables, but sometimes described as weeds because they usually grow in rough open ground and waste places. In spite of the abundance and utility of Crassocephalum species, they remain un-cultivated, under-exploited and under-utilized due to various numbers of factors (Okeno et al., 2003; Grubben and Denton, 2004).

A comprehensive treatise on phylogeny and classification cannot exclude the use of knowledge of cytological characters and a careful treatment or handling of cytological data is a more trustworthy approach in assessing evolutionary relationships (Dutta, 1988). Information on chromosome number has been used to verify or refute classification of many families (Stebbins, 1966). Heywood (1976) reported that chromosomes counts have been made for fewer than $10 \%$ flowering plant species and that not all of these counts are reliable, as many were obtained in the early days of cytology and was probably erroneous due to faulty techniques or for other reasons such as mis-identification of the species. Unlike other genera in the family Asteraceae, a review of literature on the genus Crassocephalum revealed that information on chromosome counts have not been a subject of extensive cytological investigations. Where efforts have been made on the genus genetically, reports of such efforts were preliminary and subject to review (Olorode and Okoli, 1978).

The main objective of this study is to carry out mitotic studies on the species of Crassocephalum to ascertain their somatic chromosome numbers. This is with a view to revealing the basis of the phenotypic and genetic relationships among the different species of the genus.

\section{Materials and Methods}

Achenes (fruits) were obtained during series of field trips covering different ecological locations in southwestern Nigeria between October 2005 and September, 2006 (for locations see Table 1). Herbarium specimens at the Forestry Research Institute of Nigeria (FRIN) and Obafemi Awolowo University Ile-Ife, Nigeria were used as guide to identify the collected species.

Mitotic studies were carried out on all the species studied using root tips generated from achenes plated on moistened filter paper in Petri dishes. Roots were also initiated by dipping the base of the vine in conical flasks filled with water for $C$. biafrae. The young roots were prefixed in $0.04 \%$ colchicine solution when the radicles were about $1.0 \mathrm{~cm}$ long for three hours between the hours of 9:00am and 12:00noon. After prefixation, the roots were fixed in 1:3 acetic acid/ethanol $(\mathrm{v} / \mathrm{v})$ for 24 hours before used. The roots were hydrolyzed in $1 \mathrm{~N}$ 
HCL for five minutes and rinsed with clean tap water to soften the tissue of the roots. Squashing techniques described by Olorode (1974) and as modified by Adegbite and Olorode (2002) were adopted in slide preparation.

Slides were prepared by squashing the root tips of the hydrolyzed roots (one at a time) using mounted needle and irrigating with the fixative to obtain homogenous solution. A drop of FLP-orcein stain was dropped on the squashed root before applying the cover slip. The prepared slides were left for some time (ranging from one to five hours depending on the stainability of the species) before tapping out the excess stain to spread out the cells. The slides were observed under the microscope for dividing cells. Photomicrographs of good mitotic stages were taken at X1000 magnification under oil immersion using a Leica 2000 phase contrast microscope. The photographs were printed at a constant enlargement.

\section{Results and Discussion}

The species investigated revealed large chromosomes that are clearly distinguished and counted at metaphase plates. Crassocephalum rubens, $C$. biafrae and $C$. togoense showed somatic chromosome counts of $2 \mathrm{n}=20$ with only $C$. crepidioides showed somatic chromosome counts of $2 \mathrm{n}=40$ probably being polyploid. The Somatic chromosome counts of $2 \mathrm{n}=20$ made for three species of Crassocephalum namely, C. rubens, $C$. togoense, and C. biafrae while $2 \mathrm{n}=40$ made for $C$. crepidioides respectively confirmed or corroborated earlier preliminary chromosome counts by (Olorode and Okoli, 1978), though B chromosomes were reported in $C$. rubens by (Olorode and Okoli, 1978). All C. biafrae chromosomes were large and equal in length (Plate 1D ). The somatic chromosomes of $C$. togoense were grouped into three based on there size; one pair was small, five paris were intermidate and the remaining four pairs were large (Plate 1A ). Small chromosomes were observed in C. crepidioides (Plate 1C). The chromosomes were equal to subequal in C. rubens (Plate 1D). All chromosomes were acrocentric except for C. biafrae that was metacentric.

From the chromosome counts, it becomes evident that three of the species, namely $C$. rubens, $C$. togoense, and C. biafrae are diploids while C. crepidioides is tetraploid. The chromosome counts of $2 n=40$ is high enough to be considered to be polyploid counts. This assertion is made from the fact that the angiosperm had been reported to have original (basic) chromosome numbers ranging between $\mathrm{x}=7$ and $\mathrm{x}=9$ (Heywood, 1976). With this point, any chromosome counts from about $\mathrm{n}=14$ upward are of polyploid origin. Robinson (1981) reported the basic chromosome number for the family Asteraceae to be $\mathrm{x}=8$ or $\mathrm{x}=9$.

From the claims of Heywood (1976) and Robinson (1981) on basic chromosome numbers of the angiosperms and species of the family Asteraceae, it can be deduced that the chromosome counts of $2 \mathrm{n}=40$ for C. crepidioides were polyploid or a tetraploid counts while $2 \mathrm{n}=20$ species will be diploids. Though the evolutionary origin of the tetraploid species is not yet ascertained, it is not unlikely that the diploid species are involved in the evolution, either through auto-polyploidization of any of the diploid species or allopolyploidization of natural hybrids obtained from certain combinations of the diploid species (Olorode and Okoli, 1978). However, this ascertion will require experimental confirmation through artificial hybridization experiments.

\section{Conclusions}

In all cases, our findings corroborated with the earlier counts which further revealing the basis of the genetic relationships among the different species of the genus. The basic chromosome number of $n=10$ was confirmed for the genus. Further studies should be directed to the morphology and reproductive biology of the genus to justify there phenotypic relationships.

\section{References}

[1]. J. J Hutchinson and J. M. Dalziel, Flora of West Tropical Africa (London: Avi Publishing Westport R.W.J. Crown Agents, 1963).

[2]. O. Olorode, Chromosome numbers in Nigerian Compositae, Bot .J. Linn. Soc 68, 1974, 329-335.

[3]. O. Olorode, and B.B Okoli, Cytogenetic studies in some Nigerian species of Crassocephalum. (Senecioneae- Compositae), Niger. J. Genet. 2, 1978, 81-90.

[4]. M.O. Bankole, M. Ayodele, and O.T Adejumo, The antimicrobial effects of some Asteraceae commonly eaten as vegetables in Southwest Nigeria on some enteric pathogens, Comp. Newsletter 40, 2003, 56-61.

[5]. A. O. Olufolaji and O. A. Denton, Vegetable programme ( National Horticultural Research Institute (NIHORT). 25years of Research into Horticultural Crops Development in Nigeria. NIHORT Printing Press, Ibadan, 1975-2000).

[6]. J. A. Okeno, D. K Chebet, and P. W, Mathenge, Status of indigenous vegetable in Kenya, Acta Hort. 6 (21), 2003:95-100.

[7]. G. J. H. Grubben and O.A Denton, Plant resources of tropical Africa, Vegetables (PROTA Foundation Wageningen Leiden: CTA Wageningen, 2004).

[8]. S.C. Dutta, Systematic botany (India: Wiley Eastern Limited, 1988).

[9]. G. L. Stebbins, Chromosome variation and evolution. Science, 15 (2), 1966, 1463-1469.

[10]. V. H. Heywood, Plant taxonomy (London: Edward Arnold Publishers Ltd, 1976 ) .

[11]. A. E. Adegbite, and O. Olorode, Meiotic studies of some populations of three species of Aspilia Thouars (Heliathae-Asteraceae) in Nigeria, Nig. J. Bot. 15, 2002, 74-53.

[12]. H. Robinson, A review of the tribal and sub-tribal limit of Helianthae (Asteraceae), Smithsonian contribution to Botany. 1981, 51-59. 


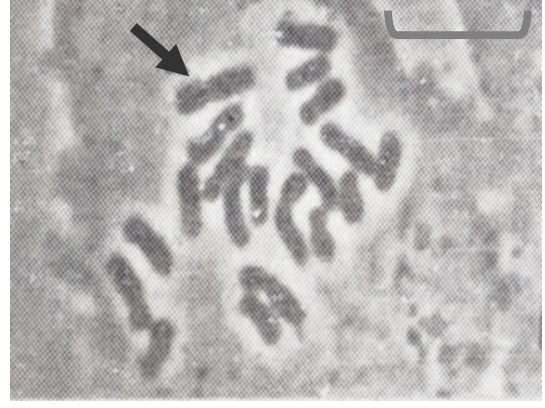

$\Delta$

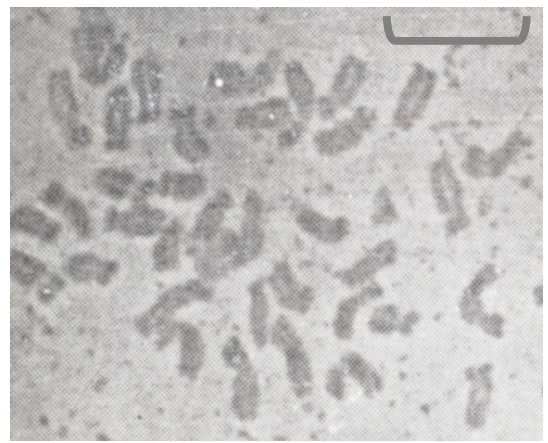

C

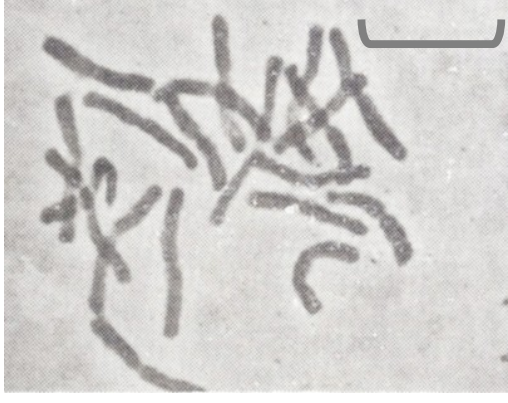

B

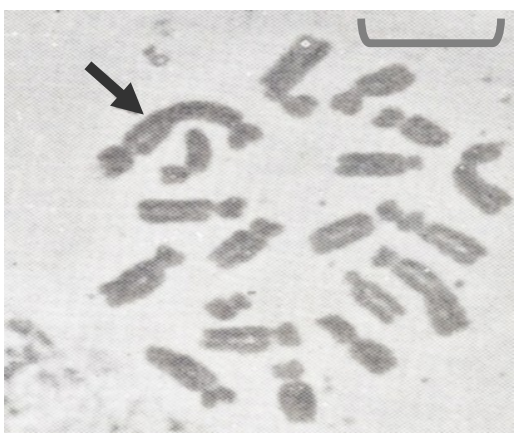

D

Plate 1: Mitotic chromosomes in some accessions of all species of Crassocephalum studied.

Scale line represents $5 \mu \mathrm{m}$.

A. Metaphase in $C$. togoense $(2 \mathrm{n}=20)$

B. Metaphase in C. biafrae $(2 \mathrm{n}=20)$

C. Metaphase in C. crepidioides $(2 \mathrm{n}=40)$

D. Metaphase in C.rubens $(2 \mathrm{n}=20)$

TABLE 1: Location \& Collection Data of Field Populations of $C$. crepidioides, $C$. rubens, $C$. biafrae \& $C$. togoense Name \& accession number of species Location of collection Description of location

\begin{tabular}{lllllll}
\hline C. crepidioides & (Benth.) & S. & Moore & Routes: Osiele village, along Ibadan- & Guinea \& Derived savannah in
\end{tabular} $\mathrm{AS} / 010,012,015,018, \& 022$ Abeokuta road, No. 21, Gbada Salam yam/Maize farmland, vegetable Street, Idimu Lagos, Adodo village, Igbeti/Ogbomoso, Aguo village Ibadan-Oyo garden, waste place, roadside road, University of Ado-Ekiti campus.

C. rubens (Juss. Ex Jacq.) S. Moore (purple floret) AS/001, 004, 005, 009, 014, $\& 017$

C. rubens (Juss. Ex Jacq.) S. Moore (light purple floret) AS/002, 003, 006, 007 \& 016

C. rubens (Juss. Ex. Jacq.) S. Moore (white floret) AS/013,019 \& 020

C. biafrae (Olive. Hiern)

S. Moore AS/008 \& 011

C. togoense C.D. Adams AS/021 \& 023
Routes: Guguru village along

Igbeti/Ogbomoso Adodo village, near Ogbomoso, Obantoko/Adatan,Asero, Abeokuta, Okuku, along Ikirun/Ilorin road. Guguru village, near Ogbomoso/Igbeti, roadside, besides local government secretariat, Epe.

Routes: Telemu village along Iwo-Osogbo road, Gurugu village, along

Ogbomoso/Igbeti, Aramoko-Ado-Ekiti road. Joju village, Sango-Otta

Routes: Igbeti township, Oru/Ijebu Igbo road. Ibadan/Abeokuta; Bakatari Township

Routes: Fiditi along Oyo-Ibadan road. , Moniya

Routes: Apomu Ikire; Eleekara, via Idi-Igba, Ilora, Ibadan -Oyo road.
Derived \& Guinea savannah in yam/maize farm, road side, yam/pepper farmland, cleared land

Guinea \& Derived savannah in yam farmland, waste place by the roadside, abandoned plot of land, uncultivated burnt forest

Guinea \& Derived savannah in Yam farmland, waste place roadside in dilapidated building

Derived Savannah with loamy soil; Cocoa plantation.

Derived Savannah with sandy loamy soil; abandoned farmland and weedy roadsides. 